\title{
Identification of Student's Critical Thinking Skills on Cryptogamic Based on Digital Argumentation Performance through Online Learning
} \author{
Akhmad Sukri ${ }^{4}$, Rusdi Hasan ${ }^{5}$ \\ ${ }^{1}$ Dept of Biology Education, Universitas PGRI Madiun, Indonesia \\ ${ }^{2}$ Dept of Physics Education, Universitas PGRI Madiun, Indonesia \\ ${ }^{3}$ Dept of Mathematics Education, Universitas PGRI Madiun, Indonesia \\ ${ }^{4}$ Dept of Biology education, Universitas Pendidikan Mandalika, NTB, Indonesia \\ ${ }^{5}$ Dept of Biology education, Universitas Muhammadiyah Bengkulu, Indonesia \\ *Corresponding author. Email: lukitasari@unipma.ac.id
}

Marheny Lukitasari ${ }^{1 *}$, Risma Ristanti ${ }^{1}$, Jeffry Handhika $^{2}$, Wasilatul Murtafiah ${ }^{3}$,

\begin{abstract}
This study was conducted to identify students' critical thinking and argumentation skills based on digital argumentation (DA) performed through eLMA-based online learning. The research method was descriptive qualitative. The data collection technique in this research was digital argumentation which was reflected through the arguments expressed online and digital documentation quantification by rubric critical thinking and DA skills. The data of critical thinking and DA skills analysis descriptively, whereas the correlation between critical thinking and DA skill was analyzed with Pearson correlation test. The results showed that students' critical thinking skill based on digital argumentation (DA) performance through eLMA-based online learning on Cryptogamic course is at moderate level which composed of high level of $42 \%$, moderate level of $29 \%$, and low level of $29 \%$. The average of students' DA skill has the same category as critical thinking skill at moderate category with slightly different distribution level, however. Student DA skills with category high, moderate, and low levels are $41 \%, 24 \%$, and $35 \%$, respectively. The Pearson correlation analysis showed that there was relationship in strong category between students' critical thinking and DA skills based on digital argumentation (DA) performance through eLMA-based online learning.
\end{abstract}

Keywords: Critical Thinking, Digital Argumentation, e-Learning, UNIPMA

\section{INTRODUCTION}

E-learning is becoming a very popular way especially in the educational sector along with the advance of information communication technology (ICT) and the condition of Covid-19 pandemic worldwide that impacted to all sectors of human life. E-learning is also called online learning, computer-assisted learning, internet or web-based instruction [1]. There is an extensive term of e-learning as given by different institutions and researchers. According to European Commission (2001), e-learning refers to the use of new multimedia technologies and the internet to increase learning quality by easing access to facilities and services as well as distant exchanges and collaboration. Whereas,
OECD (2005) defined e-learning as the use of ICT in diverse processes of education to support and enhance learning in institutions of higher education. The term of e-learning refer to the using ICT for accelerating performance and knowledge [1], and enabling access to online teaching and learning resources [3]. E-learning is an effective learning process produced by combining digital delivery of material consisting of learning support and services (Barbara, 2008). Clark \& Mayer (2016) defined e-learning as the instructions that is provided through digital devices with the intent of supporting learning.

Of the many definitions of e-learning, all of them in simply refer to the use of electronic media networks in learning activities. E-learning is an innovation in 
education that contributes greatly to the changing in the learning environment. E-learning provides students to be more active in the learning process without boundary of location and time as in the conventional learning. Teaching materials can be packaged in various dynamic format using internet resources that is interactive, interesting, and entertaining form of teaching and learning. Therefore, e-learning is becoming the future popular learning strategy in education [5]. The application of e-learning in Biology Education is urgency necessary to improve students' understanding of the material and critical thinking through online or webbased platform.

We developed e-Learning Management System of University PGRI Madiun (eLMA) that using some learning application such as Edmundo. One of eLMA goal is to identify students' high order thinking skills that is performed in online-based learning activity. Critical thinking is one of the $21^{\text {st }}$ century skills needed for better societal and civic participation as well as better employment in the global scale of life competition [6] due to critical thinking skills can help students assess the accuracy of information that they find and avoid illogical thinking and other common mistakes in reasoning [7]. Critical thinking along with problem solving are encompassed in higher order thinking skills. Critical thinking is the ability to analyze facts, generate and organize ideas, defend opinions, make comparisons, draw inferences, evaluate arguments and solve problems [8]. These terms indicate that critical thinking skills are closely related to the ability to argue because to convey a good argument, it takes insight and understanding of the material being studied.

Argumentation skill is a very important process in learning and is a form of externalizing communication as efforts for human outpouring or expression into the world both in mental and physical activities. The challenge of critical thinking is often based on arguments [9].Therefore, students' critical thinking can be measured through the performance of argumentation as well as in text and digital form or digital argumentation (DA). Digital argumentation (DA) is a major component of human intelligence. Digital argumentation aims to detect arguments that appear in text documents (Leuven, 2009). Critical thinking can and should be taught in every discipline and at all levels of education[9]. Fostering critical thinking as students learning outcome in the form of digital argumentation is very suitable to be applied in various types of courses, one of which is the Cryptogamic course. In this study we identify the students' critical thinking and DA skills as well as analyze its correlation based on digital argumentation performance through online base learning practice by eLMA in University of PGRI Madiun.

\section{THEORETICAL REVIEW}

\subsection{Critical thinking}

Critical thinking has been defined by many experts in extending fields of science [7], [10] and has a bit changed in the last decade or so may even change in the future [11]. Chance \& Brandt (1986) Chance \& Brandt (1986) defined critical thinking as the ability to analyze facts, generate and organize ideas, defend opinions, make comparisons, draw conclusions, evaluate arguments, and solve problems. Ennis (2011) defines critical thinking as reasonable reflective thinking that focuses on deciding what to believe or do. Some other experts define critical thinking as the mental processes, strategies, and representations that a person uses to solve problems, make decisions, and learn new concepts [13]; the use of cognitive skills or strategies that increase the likelihood of a desired outcome [14]; and seeing both sides of the problem, being open to new evidence that disproves ideas, reasoning without feeling, demanding that claims be supported by evidence, inferring and inferring conclusions from available facts, and solving problems [15]. Referring to various definitions, critical thinking is briefly defined as a purposeful self-regulatory appraisal process that drives problem solving and decision making, or the "machine" that drives how we decide what to do or believe in each context. Of the various critical thinking terminology that varies and changes over time as the development of ICT, there is one thing that will remain constant, it is the need to provide effective solutions to the complex problems that student faces [11].

\subsection{Argumentation}

An argumentation is a statement that is supported by objective data and facts so that can be used to change or influence the minds of others [16]. The ability to argue is the ability that a person has, to strengthen or reject opinions by providing evidence and logical principles so that others believe in the opinions expressed [17]. The term of argumentation refers to persuasive processes, construction, and metacognition [18]. Argumentation involves the process of considering an issue or issue to arrive at a considered or reasonable position and involves drawing on relevant information or data about an individual or group's understanding of the problem and personal and societal values [19]. The development ICT provides technology-based argumentation involving many people, especially in the digital community by exploring various kinds of information pathways through patterns of images, words, narratives and data collections [20]. This concept reinforces the condition that there has been a shift in the form of communication that originally required direct meetings, so with the development of technology one will be able to express opinions in digital format called digital argumentation (DA) or 
online argumentation [20]-[22] which can be done through the support of integrated application systems based on internet networks as in eLMA [22]. Argumentation skills will sharpen and enhance HOTs which includes critical thinking. The quality of the argument that students can articulate reflects the quality of the learning they master [23]-[25].

\section{METHOD}

This research is descriptive qualitative study that present the results of study as construction of thoughts and interpretations of the observed object. The research sample were 32 of $3^{\text {rd }}$ semester students of Biology Education at University of PGRI Madiun. The research instrument used a rubric assessment of critical thinking based on digital argumentation data. The data collection technique in this research was digital argumentation which was refl ected through the arguments expressed by students in discussions conducted in online forums at eLMA and digital documentation. The students' critical thinking skills analyzed referring to the rubric of scoring critical thinking skills and percentage analysis of digital abilities.

\section{RESULT AND DISCUSSION}

The critical thinking skill of Biology Education students of UNIPMA which refers to digital argumentation (DA) data collected through online learning on the eLMA platform in the Cryptogamae course is shown at Figure 1. The result showed that critical thinking skills of biology education students of UNIPMA with high category are the largest portion (41\%) compared to the students with other categories. Overall, the level of students' thinking skill was at the moderate category.

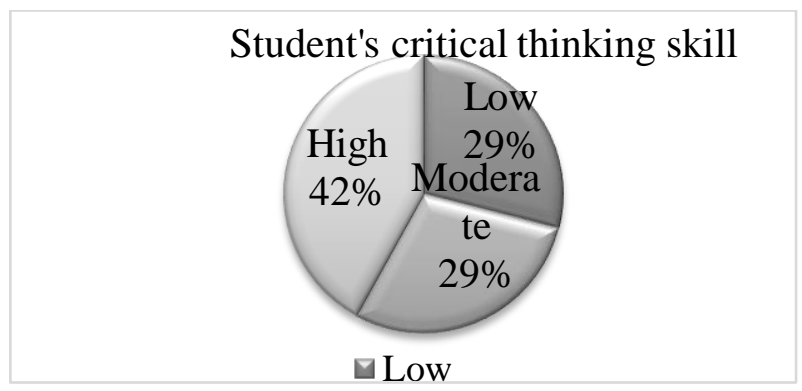

Figure 1. Students' critical thinking skill in Cryptogamic through e-learning

The argumentation skill of Biology Education students of UNIPMA that was expressed through digital argumentation format is presented at Figure 2 below. The students who possess argumentation skill in high level category are 42 percent and are the highest number to those with moderate and low levels category by 29 percent each. Overall, the level of students' DA skill was at the moderate category.

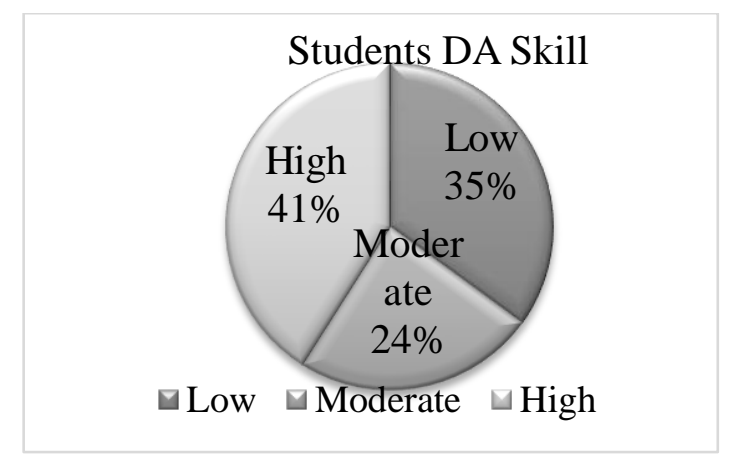

Figure 2. Students' digital argumentation skill in Cryptogamic through e-learning

We conducted Pearson's correlation using the IBMSPSS version 26.00 for Windows to analyze the relationship between students' critical thinking and argumentation skills based on digital argumentation (DA) performance of Cryptogamic through online learning on eLMA platform of UNIPMA. The result of Pearson correlation test obtained the Pearson correlation value of 0.740 and $\mathrm{Sig}$ value of 0.00 . The value of $\mathrm{r}$-table in alpha 0.05 is 0.349 . The result showed that Sig value $0.000<0.05$ and Pearson correlation value of $0.740>\mathrm{r}$ table of 0.349 Those results confirm that there is a relationship between students' critical thinking and argumentation skills based on digital argumentation (DA) performance of Cryptogamic through online learning on eLMA platform of UNIPMA. The relationship level between them is high/strong category.

The results showed that the average of students' critical thinking skill in Cryptogamic course was moderate category with the composition of $42 \%$ high, $29 \%$ moderate, and $29 \%$ low in the Cryptogamic. The same cade with the students' DA skill was moderate category with a slightly different composition which consist of $41 \%$ high, $24 \%$ moderate, and 35\% low categories. These results provide a positive indication of the implementation online learning on the eLMA platform in developing students' critical thinking and argumentation skills based on DA form along with the cessation of conventional learning activities in the form of face to face in classrooms during pandemic Covid-19. The sudden change of learning activities from offline or blended learning to fully online during pandemic Covid19. It presents challenges, expectations, and obstacles that must be overcome so that the results of learning practices can be applied in accordance with the learning goals that have been formulated. Obstacles that often appear in the implementation of online learning include the ability of lecturers and students to use ICT in learning activities, limited funds related to internet quotas, and the internal LMS platform as the main alternative media or facility in addition to the general platform which can be 
obtained globally and may be free of charge but with many limitations [26], [27].

The combination of the medium and high categories on the profile of students' critical thinking skills and DA were more than $70 \%$ and $65 \%$, respectively. Meanwhile students with low categories of both skills were $29 \%$ and $35 \%$. These results were a positive indication of the elearning outcomes which were represented in the form of DA skill through eLMA in developing students' HOTs. It is because the implementation of online learning is relatively a new experience for both students and lecturers, as well as the developing eLMA. These results also provide a good expectations and opportunity in improving student critical thinking and DA skills along with getting used to with online learning features including eLMA as an internal LMS and the main platform for e-learning application at UNIPMA. Elearning refers to the use of information and communication technology to allow access to learning resources to increase the interactivity of students' learning experiences through collaborative learning, cultural diversity, globalization, and erasing the boundaries of place and time [3]. The most vital characteristic, as well as the advantages of e-learning in education is the student-centered learning [28]. In online learning, each student or group of students gets the same and widest opportunity to express their thoughts without anyone who dominate as in the offline learning [29]. It makes online learning more effective in encouraging the high ability of students in their DA performance than offline learning [25]. In e-learning students can assimilate information as well as or even better than students who study in the traditional way [30] and has proven to be effective especially in the case of shy, easily intimidated, and slow learners who usually do not have the courage to speak and express in the traditional offline classroom [31].

This study showed a correlation with a high category between the students' critical thinking skill and DA skills in the Cryptogamic course. The result supported previous study that indicated argumentation can grow critical thinking skills (Hasnunidah, 2020; Indrawatiningsih, 2018; Suryani et al., 2021). Argumentation and critical thinking are closely related [36] due to the indicators of both skills require a high cognitive ability. Argumentation includes not only arguments, but also wider dialogue, discussion, persuasion, and disagreement with others. Argumentation is not just another form of reasoning but is an activity that involves reasoning and persuasion [21]. Argumentation requires specific and systematic steps and thought processes. A good argument displays the completeness of the components of the argument that are arranged in a systematic way [37]. Digital argumentative is not only about words, phrases, and sentences but also a complex process involving topics, statement development, and coherent organizing and conveying ideas into writing. Critical thinking skills are needed to write good arguments. The ability to think critically correlates with the quality of the arguments performed. Students who have good critical thinking skills also have good argumentative writing skills, while students who lack critical thinking also tend to have low argumentative writing skills.

\section{CONCLUSION}

The profile of critical thinking skill of Biology Education students of UNIPMA based on digital argumentation (DA) performance through eLMA-based online learning at UNIPMA on Cryptogamic course is at moderate level category which is distributed into high level of $42 \%$, moderate level of $29 \%$, and low level of $29 \%$. Meanwhile, the average of overall students' DA skill has the same category as critical thinking skill at moderate category with slightly different distribution level, however. Student DA skills with category high, moderate, and low levels are $41 \%, 24 \%$, and $35 \%$, respectively. The Pearson correlation analysis showed that there was relationship in strong category between students' critical thinking and DA skills in Cryptogamic based on digital argumentation (DA) performance through eLMA-based online learning.

\section{ACKNOWLEDGMENTS}

The authors acknowledge to the Ministry of Education, Research, and Technology for funding the research through Research Grant at 2020/2021 in PTUPT program.

\section{REFERENCES}

[1] J. G. Ruiz, M. J. Mintzer, and R. M. Leipzig, "The impact of e-learning in medical education," Acad. Med., vol. 81, no. 3, pp. 207-212, 2006, doi: 10.1097/00001888-200603000-00002.

[2] OECD, "E-learning in Tertiary Education," Policy $B r$. no. December, 2005, [Online]. Available: https://www.oecd.org/education/ceri/35991871.pdf

[3] V. Arkorful and N. Abaidoo, "The role of e-learning , advantages and disadvantages of its adoption in higher education .," Int. J. Instr. Technol. Distance Learn., vol. 12, no. 1, pp. 29-43, 2015.

[4] R. C. Clark and R. E. Mayer, e-Learning and the Science of Instruction, 4th editio. San Francisco, CA: Pfeiffer, 2016.

[5] S. Goyal, "E-Learning : Future of Education," vol. 6, pp. 239-242, 2012.

[6] R. R. Guleker, "Instructional strategies to foster critical thinking: self-reported practices of the faculty in Albania," Int. J. Teach. Educ., vol. III, no. 4, pp. 6-14, 2015, doi: 10.20472/TE.2015.3.4.002. 
[7] D. D. Chiras, "Teaching Crtcal Biology Science Thinking Skills in the Environmental Classrooms," Am. Biol. Teach., vol. 54, no. 8, pp. 464-468, 2015.

[8] P. Chance and R. S. Brandt, Thinking in the classroom: a survey of programs. New York (N.Y.): Columbia university. Teachers college press, 1986

[9] J. S. Wilson, "Promoting Critical Thinking In General Biology Courses: The Case Of The White Widow Spider," J. Empower. Teach. Excell., vol. 1, no. 2, 2017, [Online]. Available: http://digitalcommons.usu.edu/jete\%0Ahttp://digita lcommons.usu.edu/jete/vol1/iss2/9.

[10] I. J. Quitadamo et al., "Community-based Inquiry Improves Critical Thinking in General Education Biology Community-based Inquiry Improves Critical Thinking in General Education Biology," 2008, doi: 10.1187/cbe.07.

[11] V. Schneider, "Critical Thinking in the Elementary Classroom: Problems and Solutions," Educ. Publ. Serv., pp. 1-3, 2002.

[12] R. H. Ennis, "The nature of critical thinking: an outline of critical thinking dispositions," in Sixth International Conference on Thinking at MIT, 2011, pp. $\quad 1-8, \quad$ [Online]. Available: https:/education.illinois.edu/docs/defaultsource/faculty-documents/robertennis/thenatureofcriticalthinking_51711_000.pdf?s fvrsn=7bb51288_2.

[13] R. J. Sternberg, “Critical Thinking: Its Mature, Measurement, and Improvement.," Natl. Inst. Educ., pp. 1-37, 1986.

[14] D. F. Halpern, "Teaching critical thinking for transfer across domains. Dispositions, skills, structure training, and metacognitive monitoring.," The American psychologist, vol. 53, no. 4. United States, pp. 449-455, Apr. 1998, doi: 10.1037//0003066x.53.4.449.

[15] D. T. Willingham, "Critical thinking: why is so hard to teach," Am. Educ., vol. 109, no. 4, pp. 8-19, 2007 , doi: 10.3200/AEPR.109.4.21-32.

[16] R. M. Palau and M. F. Moens, "Argumentation mining: The detection, classification and structure of arguments in text," Proc. Int. Conf. Artif. Intell. Law, pp. 98-107, 2009, doi: 10.1145/1568234.1568246.

[17] A. Afandi, "Pentingnya keterampilan argumentasi di era ledakan informasi digital," no. August, 2020.

[18] A. Morgan, "Argumentation geography education and ICT," Geography, vol. 91, no. 2, pp. 126-140, 2006, doi: 10.1080/00167487.2006.12094158.

[19] P. A. Kirschner, S. J. Buckingham-Shum, and C. S. Carr, Visualizing Argumentation: Software Tools for Collaborative and Educational Sense-Making.
London, UK: Springer-Verlag London, 2003.

[20] K. L. Kelly, "Emergent Arguments: Digital Media And Social Argumentation,” 2016.

[21] Y. C. Fan, T. H. Wang, and K. H. Wang, "Studying the effectiveness of an online argumentation model for improving undergraduate students' argumentation ability," J. Comput. Assist. Learn., vol. 36, no. 4, pp. 526-539, 2020, doi: $10.1111 /$ jcal.12420.

[22] M. Lukitasari, J. Handika, W. Murtafiah, and A. R. Nurhikmawati, "Examining students' SelfAssessment of Digital Argumentation (SADA) in ebiology class: A Rasch analysis," JPBI (Jurnal Pendidik. Biol. Indones., vol. 6, no. 2, pp. 209-216, 2020, doi: 10.22219/jpbi.v6i2.11919.

[23] F. Macagno, E. Mayweg-Paus, and D. Kuhn, "Argumentation Theory in Education Studies: Coding and Improving Students' Argumentative Strategies," Topoi, vol. 34, no. 2, pp. 523-537, 2015, doi: 10.1007/s11245-014-9271-6.

[24] S. Villata, G. Boella, and L. van der Torre, "Argumentation Patterns," 8th Int. Work. Argumentation Multi-Agent Syst. (ArgMAS 2011), pp. 133-150, 2011, [Online]. Available: http://www-

sop.inria.fr/members/Serena.Villata/Resources/arg mas11.pdf.

[25] N. Soundarajan and S. Joshi, "Innovative approach to online argumentation and models for structuring the arguments," Proc. - Front. Educ. Conf. FIE, vol. 2018-Octob, pp. 1-9, 2019, doi: 10.1109/FIE.2018.8658585.

[26] J. Suprapmanto, "Analisis Permasalahan Pembelajaran Daring selama Pandemi Covid 19 dan Solusinya," vol. 3, no. 2, pp. 15-19, 2021.

[27] M. Pradana and S. Syarifuddin, "The Struggle Is Real : Constraints of Online Education in Indonesia During the COVID-19 Pandemic," vol. 6, no. September, pp. 2020-2021, 2021, doi: 10.22219/jppg.v1i1.12462.

[28] B. Holmes and J. Gardner, e - Learning: Concepts and Practice. London, Thousand Oaks, New Delh: SAGE Publications Inc., 2006.

[29] V. Sampson and D. B. Clark, "Assessment of the ways students generate arguments in science education: Current perspectives and recommendations for future directions," Sci. Educ., vol. 92, no. 3, pp. 447-472, 2008, doi: $10.1002 /$ sce. 20276 .

[30] P. Navarro and J. Shoemaker, "Performance and perceptions of distance learners in cyberspace," Am. J. Distance Educ., vol. 14, no. 2, pp. 15-35, Jan. 2000, doi: 10.1080/08923640009527052.

[31] B. S. Stern, “A Comparison of Online and Face-To- 
Face Instruction in an Undergraduate Foundations of American Education Course," vol. 4, pp. 196213, 2004.

[32] L. A. Suryani, H. P. Putri, and H. Khair, "THE CORRELATION BETWEEN STUDENTS CRITICAL THINKING AND ARGUMENTATIVE WRITING SKILLS AT," vol. 2, no. 1, pp. 65-75, 2021.

[33] L. E. Ferguson and J. Bubikova-moan, "Argumentation as a pathway to critical thinking," pp. 1-11.

[34] N. Indrawatiningsih, "Arguments in Critical Thinking Ability," no. September, 2018, doi: 10.2991/icomse-17.2018.4.

[35] N. Hasnunidah, "The contribution of argumentation and critical thinking skills on students ' concept understanding in different learning models," vol. 17, no. 1,2020 .

[36] R. Andrews, "Critical Thinking and / or Argumentation in Higher Education," in The Palgrave Handbook of Critical Thinking in Higher Education, 2015, pp. 49-50.

[37] S. E. Toulmin, The Uses of Argument, Updated Edition. Cambridge, UK: Cambridge University Press, 2003. 